Danmarks geologiske Undersøgelse.

IV. Række. Bd. 2. Nr. 11.

\title{
Om Fund
}

\author{
af \\ Tøndersvamp (Polyporus fomentarius (L.) FR.) \\ fra Postglacialtiden i Danmark.
}

\author{
Af \\ N. Fabritius Buchwald og Sigurd Hansen.
}

With an English Summary.

København.

I Kommission hos C. A. Reitzels Forlag.

1934

Pris: 75 Øre. 
Danmarks geologiske Undersøgelse.

IV. Række. Bd. 2. Nr. 11.

\title{
Om Fund
}

af

Tøndersvamp (Polyporus fomentarius (L.) FR.) fra Postglacialtiden i Danmark.

\author{
Af \\ N. Fabritius Buchwald og Sigurd Hansen.
}

With an English Summary.

København.

I Kommission hos C. A. Reitzels Forlag. 
Under Udarbejdelsen af en Monografi over Tøndersvampen (Polyporus fomentarius $)^{1}$ ) for nogle Aar tilbage stødte den ene af Forff. til nærværende Afhandling paa en Del subfossile Eksemplarer af denne Svamp, der fra gammel Tid opbevares i Landbohøjskolens plantepatologiske Afdelings Samling. Oplysningerne om Fundforholdene for disse oftest mosefundne Eksemplarer var imidlertid ret ufuldstændige, saa man i de fleste Tilfælde ikke paa Grundlag af dem kunde give nogen geologisk Aldersbestemmelse. Den Tanke opstod derfor at forsøge at opnaa en omtrentlig Aldersbestemmelse for disse Svampefund paa samme Maade, som det i de to sidste Aartier hyppigt er blevet gjort for mosefundne Pattedyrrester og Oldsager, nemlig ved en pollenstatistisk Undersøgelse af Tørvemassen i det Lag, hvori Svampen var beliggende (se f. Eks. Knud Jessen 1920, 1927 og 1929, Hilmar Ødum 1920, Magnus Degerbol 1933). Ved Udførelsen af saadanne »Pollentællinger« for de Fund, der ikke ad anden Vej kunde tidsfæstes, faldt det naturligt at udvide Undersøgelsen til at omfatte saa vidt muligt alle fra Danmark bekendte Fund af Poresvampe. I den Anledning rettedes der Henvendelse til de Institutioner ${ }^{2}$ ), hos hvilke det kunde tænkes, at der opbevaredes Materiale af mosefundne Poresvampe.

Hovedparten af det derved tilvejebragte Materiale viste sig at være Svampe, optagne af og indsendte til vedkommende Samlinger af Lægfolk; de ledsagende Oplysninger var derfor af en saadan Art, at man af dem ikke kunde drage Slutninger om Fundenes Aldersforhold. Der var heller ikke i noget af disse Tilfælde optaget eller bevaret Tørveprøver af det Lag, hvori Fundet blev gjort. Det blev derfor nødvendigt at opsøge saadanne smaa Huller eller uregelmæssige Sænkninger i Overfladen paa Frugtlegemerne, hvor det

\footnotetext{
1) X. Fabritius Buchwal.1 (1930). Se Litteraturlisten Side 20.

2) Disse Institutioner er foruden D. kgl. Veterinær- og Landbohøjskole: Botanisk Musæum, Danmarks Geologiske Undersøgelse, Mineralogisk Musæum, Nationalmusæets 1ste Afdeling; tillige inddroges i Undersøgelsen Materiale fra Viborg Kathedralskole. - For den Velvillie, som der overalt vistes Forff. ved Henvendelsen, bringer vi herved vor bedste Tak.
} 
kunde formodes, at smaa Tørvepartikler endnu sad gemte, selv efter den mere eller mindre grundige Afvaskning, som sikkert alle Eksemplarerne havde været udsat for. Ved Udskrabning af disse Huller eller Uregelmæssigheder med Naal og Pincet var det i en Række Tilfælde muligt at sikre sig tilstrækkeligt Materiale til en Pollentælling, medens Fundets Renvaskning i andre Tilfælde desværre viste sig at have været for grundig.

Mange af Poresvampene, fortrinsvis de fleraarige, kork- og træagtige Arter, der sædvanlig henføres til Slægten Fomes Fr., egner sig ved deres haarde Konsistens fortrinlig til Opbevaring gennem lange Tidsrum. Da adskillige af dem tillige lever paa saadanne Træarter, som vokser i og omkring Moser (Betula, Populus, Alnus, Pinus etc.), var det rimeligt paa.Forhaand at vente, at vore Moser vilde rumme Levninger af flere forskellige Polyporus- (Fomes-) Arter. Der tænkes her først og fremmest paa saadanne Arter som Polyporus fomentarius, P. igniarius, P. pini, P. ungulatus (Syn. P. marginatus, $P$. pinicola). Det var derfor noget af en Overraskelse, at alle de mosefundne Polyporus-Individer, som Forff. har haft til Undersøgelse, uden Undtagelse viste sig at tilhøre een og samme Art: Tønder- eller Fyrsvampen (Polyporus fomentarius (L.) Fr.). Det skal dog straks bemærkes, at ingen af de undersøgte Eksemplarer var bestemte til Polyporus fomentarius, men enten var henført til Polyporus igniarius (L.) FR. eller til Polyporus nigricans FR. eller var ubestemte. Artsspørgsmaalet vil imidlertid blive taget op til nærmere Drøftelse længere fremme. - Det er ikke Forff. helt klart, hvorpaa det beror, at der af Moserne hidtil kun er blevet fremdraget Eksemplarer af $P$. fomentarius. Arter som den ganske nærstaaende $P$. igniarius $^{1}$ ), der som Værtplanter bl. a. har BetulaArter og Populus tremula, og P. pini, der lever paa Pinus silvestris, synes umiddelbart baade ved deres haarde Konsistens og deres Værtplanteforhold at have mindst lige saa gode Betingelser for at blive opbevaret gennem lange Tidsrum som $P$. fomentarius. Indrømmes skal det ganske vist, at de to nævnte Polyporus-Arter i Nutiden er betydeligt sjældnere i Danmark end Tøndersvampen, og muligvis er Forklaringen paa, at de ikke er fundne i vore Moseaflejringer den, at de ogsaa i tidligere Tid har været sjældne, om end deres Værtplanter, Betula-Arter, Populus tremula og Pinus silvestris, maa antages at have været almindeligere end nuomstunder. I Skan-

1) Heri indbefattes ikke $P$. fulvus (pomaceus), Blommeporesvampen. 
dinavien og Finland derimod er saavel Polyporus pini som især $P$. igniarius meget almindelige Svampe.

De danske postglaciale Fund af Tøndersvampen kan væsentlig henføres til to Fundgrupper:

a. Bopladsfundene, som kan tidsfæstes ad arkæologisk Vej; hertil hører kun et Par af Fundene: Nr. 8 og 14.

b. Mosefundene. Disse falder atter i to Kategorier. Enkelte af dem: Nr. 11, 12 og 13 er nemlig ret nøje beskrevne og kan saaledes tidsfæstes med nogenlunde Sikkerhed, men om Størsteparten af Fundene gælder det, at Oplysningerne om Fundforholdene er saa sparsomme eller vage, ja oftest helt mangler, at de — som foran antydet — slet ikke tillader nogen nærmere Aldersbestemmelse. Det er derfor ved denne sidste Gruppe Fund, at man kunde vente nogen Oplysning ved pollenstatistiske Undersøgelser af de eventuelt vedhængende Tørverester.

I efterfølgende Fortegnelse er opført alle de os bekendte postglaciale Fund af Tøndersvamp i Danmark, ialt 16 Fund. Utvivlsomt vil fremtidige Moseundersøgelser forøge Listen betydeligt, og det vilde navnligt være interessant, om ogsaa andre Polyporus-Arter kunde blive fremdraget. Paa Kortskitsen Fig. 1 er alle Fundene indlagt; det fremgaar med Tydelighed af denne, at Findestederne ikke er lokaliseret til en enkelt Landsdel, men, som det var naturligt at vente, er nogenlunde ligeligt fordelt over hele Landet.

1. Stop Sø ved Viborg, Jylland. Svampen fundet ved Udgravning af en ikke nærmere bestemt Træstamme i en Tørvemose. Overretssagfører Jon JoHnsen legit 30. 5. 1902. Fundet bestaar kun af Brudstykker af et lille, brunfarvet Frugtlegeme. Svampen var ikke bestemt; intet af Værtplantesubstratet er til Stede. (Viborg Kathedralskoles Samling).

2. Høgild Mose, Jylland. Det ubestemte, ikke velbevarede Frugtlegeme fandtes ca. $2 \mathrm{~m}$ under Overfladen i en Mose og maaler ca. $15 \mathrm{~cm}$ i Længden; Bredde og Højde kan ikke angives; intet af Værtplantesubstratet til Stede; nærmere Oplysninger savnes. (Viborg Kathedralskoles Samling).

3. "Gaardsmose«, Grarup, Brande Sogn, Jylland. Fundet stammer fra 5 Alens Dybde. Gaardejer J. M. V. KRAG, Arvedgaard, Brande, legit 15. 6. 1922. Det hidtil ubestemte, ret fragmentariske Frugtlegeme er brunsort, $8 \mathrm{~cm}$ langt, mangler »Toppen« og Bagpartiet; ca. 5 tydelige Porelag ses; intet af Værtplanten er til Stede. (Danmarks Geologiske Undersøgelses Samling, 1929. 227). 
11. 6

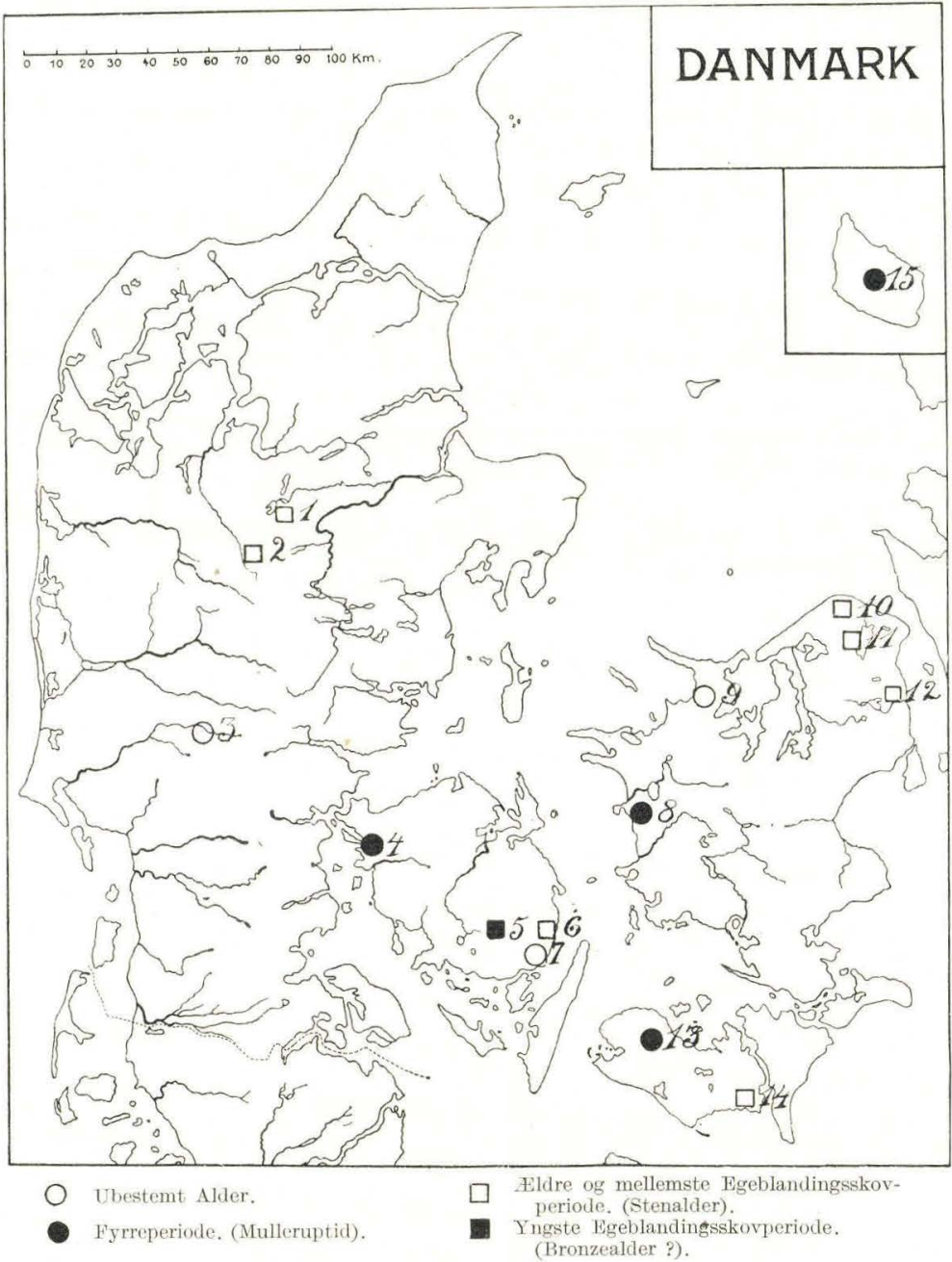

Fig. 1. Kort over danske Fund af Tondersvampen (Polyporus fomentarius). Smlgn. Fortegnelsen over Findestederne Side 5-10.

4. Barløse Sogn, Fyn. Fundet stammer fra Tørvemose. Ingeniør Elver legit 1902. Frugtlegemet, der oprindelig er bestemt til Polyporus igniarius (L.) Fr., er velbevaret, nyreformet i Tværsnit, graasort og maaler: L. 13,5, B. 9 og H. $\left.{ }^{1}\right) 9 \mathrm{~cm}$. Paa Frugtlegemet findes endnu Rester af Birkebark. (Botanisk Musæum).

5. Brændeskov, Fyn. Fundet stammer fra Tørvemose. EmrL Rosthup legit 24. 4. 1878. Frugtlegemet, hvis »Top« delvis mangler,

1) L. = Længde, B. = Bredde, H. = Højde. 
og som iøvrigt paa Overfladen er stærkt forvitret, maaler: L. 10, B. 7.5, og H. ? cm. Intet af Værtplantesubstratet er til Stede. (Landbohøjskolens plantepatologiske Samling, Nr. 3488).

6. Aabymark, Fyn. Fundet stammer fra Tørvemose. Gaardejer Hans Jensen legit. Frugtlegemet, som er ret velbevaret, er stærkt brunfarvet og maaler: L. 10, B. $4 \mathrm{og}$ H. $3.25 \mathrm{~cm}$; paa Hymeniet findes en Del Tørvesubstans; intet af Værtplantesubstratet er til Stede. Svampen var oprindelig bestemt som Polyporus sp. (Landbohøjskolens plantepatologiske Samling, Nr. 3490).

7. Vængemose, Fyn. Fundet stammer fra Tørvemose. Gaardejer Hans Jensen legit. Nærmere Oplysninger savnes. Frugtlegemet, der oprindelig var bestemt til Polyporus sp., mangler ganske Toppen og det yderste Porelag; det maaler: L. 7, B. 4,5 og H. ? cm. Intet af Værtplantesubstratet er til Stede. (Landbohøjskolens plantepatologiske Samling, Nr. 3491).

8. Maglemose ved Mullerup, Sjælland. Dette Fund er udførligt beskrevet af GEorg F. L. SARAuw (1903) i dennes Afhandling om en Stenalders Boplads i Maglemose, til hvilken der nærmere henvises $\left.{ }^{1}\right)$. Der fandtes paa Bopladsen et større Brudstykke af en Poresvamp, som Emil Rostrup bestemte til Polyporus igniarius. Da der tillige fandtes et Stykke Svovlkis og talrige Stykker Trækul, sluttede SARAUW, at Svampen var indsamlet af Stenalderfolket og af dette anvendt som Tønder ved Ildslagningen. Denne Hypotese støttede han tillige paa den Omstændighed, at Tøndersvampen og andre Poresvampe ogsaa er fundne paa andre Bopladser fra Stenog Bronzealderen i forskellige Egne af Europa. - I Følge velvillige Oplysninger fra Nationalmusæet synes den af SARAUW omtalte Svamp ikke længere at eksistere, saa en Verifikation er ugørlig.

9. Skaverup, Asminderup, Sjælland. Fundet, om hvilket udførlige Oplysninger savnes, bestaar af to velbevarede Frugtlegemer, som oprindelig indsendtes til Zoologisk Musæum, hvorfra de i November 1912 overgik til Danmarks Geologiske Undersøgelse. Det ene Frugtlegeme er ret fladtrykt, brunfarvet og maaler: L. 15, B. 12,5 og H. 7,5 cm; det andet, som nærmest er nyreformet i Tværsnit, er brunsort til sort, noget stalaktitisk og maaler: L. 11,5, B. 8 og H. 9,5 cm; paa intet af Frugtlegemerne findes der Rester af Værtplanten. Svampene var ubestemte. (Danmarks Geologiske Undersøgelses Samling, 1933. 28).

10. Udsholt, Græsted, Sjælland. Det velbevarede, brunsorte

1) Se ogsaa Buchwald (1930), S. $76-77$. 
11. 8

Frugtlegeme fandtes i ca. 6 m Dybde i Tørvemose. Gaardejer CHr. Hansen, Udsholt, legit Juli 1926. Det maaler: L. 11, B. 10 og H. $9 \mathrm{~cm}$, altsaa et højt Frugtlegeme; ingen Substratrester til Stede. (Botanisk Musæum).

11. Maglemose, Gribskov, Sjælland. Fundforholdene for dette Frugtlegeme er udførligt beskrevne af KNuD JEssen i dennes Afhandling fra 1920 (S. 104), hvortil der henvises. Frugtlegemet, der oprindeligt var bestemt til Polyporus nigricans $\mathrm{FR}^{1}{ }^{1}$ ), sad paa en større Birkestamme i et Parti af en Ælle-Birkeskovtørv, som var ganske opfyldt af Stammer og Grene af Alnus, Betula og tildels Quercus. Alle-Birkeskovtørven laa i en Dybde af $120-265 \mathrm{~cm}$ under Jordoverfladen. (Danmarks Geologiske Undersøgelses Samling).

12. Lillemose, Nordsjælland. Dette Fund er udførligt beskrevet af Iapetus Steenstrup (1842, S. 53). Skønt Etiketten til Svampen, som opbevares i Mineralogisk Musæum, bærer følgende Paaskrift: "No. 112. Egesvampen fra Egelaget i Rudersdalkromose«, lader Kortskitsen i STEenstrup's Afhandling samt Tekstens Angivelser formode, at det drejer sig om det sydlige — i N-S-lig Retning mere langstrakte - af de to nærliggende Mosebassiner, Lillemose i snævreste Forstand ${ }^{2}$ ). Frugtlegemet er fundet i de Randdannelser i Mosen, der betegnes som Egelaget og hviler paa Fyrreog overlejres af Allelaget, ikke ude i den dybe Del af Mosehullet. Om Fundet skriver Stemnstrup (S. 53): „Foruden de anførte Egelevninger fandt jeg flere Arter Plantefrø, fornemmelig Carex, Menyanthes trifoliata og en stor Egesvamp med Huller, gravede af et Insekt.« »Egesvampen« bestaar kun af et Brudstykke af et Frugtlegeme, ca. $6,5 \times 6 \times 4,5 \mathrm{~cm}$; Oversiden er blaasort, vel bevaret, bortset fra to dybe »Borehuller«, ca. $0,5 \mathrm{~cm}$ i Diameter, frembragte af et Insekt; tre tydelige Porelag er til Stede; intet af Værtplanten er bevaret. (Mineralogisk Musæum, Steenstrup-Samlingen).

13. Gallemose, Stokkemarke, Lolland. I sin Afhandling om "Gallemosen« paa Lolland, hvori dette Fund, der bestaar af to Frugtlegemer, maaske flere (smlg. Nr. 16), omtales, giver EmIL RostruP (1858) følgende Beskrivelse af det Lag, hvorfra Svampene stammer (S. 4): "Herefter fulgte det mægtigste Lag (2-6'), nemlig en sort Tørvemasse, hvori de enkelte Plantebestanddele vare ukjende-

\footnotetext{
1) Bestemmelsen ved Professor C. Ferdinanden.

2) Nutildags hedder det nordlige Mosebassin "Kromose", det sydlige "Lillemose (Se f. Eks. Kortet S. 13 hos KNud Jessen (1920)).
} 
lige, men som var gjennemvævet $\mathrm{i}$ alle Retninger med en Mængde større og mindre Trægrene og store Stammer, som det syntes navnlig af Eg og El. Derimod kunde jeg ikke finde Spor af Naale- eller Birketræer i Mosen. I samme Lag fandtes endeel Hasselnødder, vel vedligeholdte, endnu mørkrøde Frø af Iris pseudacorus, nogle meget store Træsvampe, enkelte Raabuktakker, endeel Insektdækvinger.....

Det beskrevne Tørvelag, der er et udpræget Skovlag, hvis Moderformation sandsynligvis har været et Allekrat, dækkes af et 9 Tommer tykt Muldlag og underlejres af et »Hypnumlag med Hornnødder. Af de omtalte »Træsvampe $\ll$ findes i det mindste de to endnu bevarede. Det ene graa-brunsorte Frugtlegeme (13 a) mangler noget af »Toppen«, er i Tværsnit nyreformet og noget stalaktitisk; Hymeniet er overvokset med sterilt Mycelium; det maaler: L. 16, B. 9,5 og H. 7. cm (Nr. 3482). Det andet mat brunsorte Frugtlegeme (13 b) har et dybt Hul i Toppen, men er ligesom det førstnævnte iøvrigt velbevaret; i Tværsnit næsten kredsrundt; Maalene er: L. 15, B. $15 \mathrm{og}$ H. $5 \mathrm{~cm}$. Hullet i Toppen og den kredsrunde Form lader formode, at Svampen har siddet under en Gren, hvorfra Frugtlegemet er vokset nedad. (Nr. 4003). (Landbohøjskolens plantepatologiske Samling, Nr. 3482 og 4003).

14. Nysted Nor, Lolland. Fundet stammer fra et Kulturlag fra (ældre?) Stenalder ${ }^{1}$ ), som er optaget af GEora F. L. SARAuW ${ }^{2}$ ) i 1898. Beskrivelsen af Fundomstændighederne, der er upubliceret, findes i Nationalmusæets Arkiv. Fundet omtales ganske kort af SARAUW (1903, Side 193). Frugtlegemet, der oprindelig er bestemt til Polyporus igniarius, er sort, stærkt forvitret, mangler noget af Toppen og er i Besiddelse af 5 tydelige Porelag; det maaler: L. 11,5, B. 10 og H.? cm. Værtplanterester mangler. (Landbohøjskolens plantepatologiske Samling, Nr. 3489).

15. Bornholm. Tørvemose. Amtmand P. HoLten legit 1881. Nærmere Oplysninger om Lokalitet ete. mangler ${ }^{3}$ ). EmIL Rostrup (1883) omtaler Fundet ganske kort: „Ligesom flere andre Træer har ogsaa Birken i vore Underskove været plaget af Svamp. Jeg har saa-

\footnotetext{
1) I Følge velvillig Meddelelse fra Dr. Therkel Mathiassen, Nationalmusæeet, tilhører Storsteparten af Kulturlaget den xldre Stenalder, dog findes der enkelte Genstande fra yngre Stenalder; det kan ikke ad arkæologisk Vej afgøres, hvorvidt Svampen stammer fra xldre eller yngre Stenalder.

2) Ikke som angivet paa den oprindelige Etikette: Sophus Müller, i Følge velvillig Meddelelse i Brev af 29/4 1933 fra Nationalmusaets 1ste Afdeling.

${ }^{3}$ ) Emil Rostrup's efterladte Korrespondance indeholder ingen Oplysninger om dette Fund.
} 
11. 10

ledes fra Amtmand P. HoLten paa Bornholm fra en derværende Tørvemose faaet tilsendt en subfossil Svamp, som viste sig at være en med ovennævnte (sc. Polyporus betulinus) nærbeslægtet Art, Polyporus nigricans Fries (Syst. mycol. I, 375), som endnu sad fast paa en Barkstump af Betula alba«. - Frugtlegemet er udpræget nyreformet og stalaktitisk; det maaler kun: L. 6,5, B. 3,5 og $\mathrm{H}$. $6 \mathrm{~cm}$; Birkebark ses endnu. (Landbohøjskolens plantepatologiske Samling, Nr. 3487).

16. ? Gallemose, Lolland. I Botanisk Musæums Samlinger findes der, anbragt paa en Jærnstang paa Træfod, 5 ret velbevarede Frugtlegemer af Polyporus fomentarius, som oprindelig er bestemt til Ild-Poresvamp (Polyporus igniarius). Desværre eksisterer der slet ingen Oplysninger om Findested og Fundforhold. Det er tænkeligt, at de er samlede af EMIL Rostrup i Gallemosen paa Lolland og saaledes egentlig hører sammen med de to under Nr. 13 omtalte Frugtlegemer. Herfor taler dels Størrelsen og Farven af Frugtlegemerne dels det Forhold, at Rostrup er den eneste, som tidligere i større Grad har samlet og beskæftiget sig med mosefundne Svampe i Danmark.

De fem Frugtlegemer opviser følgende Maal i cm:

$\begin{array}{lllll} & \text { Længde } & \text { Bredde } & \text { Højde } & \\ \text { a. } & 25 & 14,5 & 16,5 & \\ \text { b. } & 22 & ? & 14,5 & \text { (ufuldstændigt). } \\ \text { c. } & 19,5 & 12 & 9 & \\ \text { d. } & 12,5 & 13 & ? & \text { (»Toppen « mangler). } \\ \text { e. } & 11 & 11,5 & \text { ? } & \text { (»Toppen } \text { " mangler). }\end{array}$

Vi vil dernæst se paa de Resultater, som Forsøg paa Tidsbestemmelse gennem Pollenanalyse af de vedhængende Tørverester har givet. Der rejser sig her straks det tilsvarende Spørgsmaal som ved Forsøg paa pollenstatistisk Aldersbestemmelse af Dyrerester og Oldsager fra Mosefund (Hımar Øpum 1920, Side 14): Er de fundne Levninger af Tøndersvampen af samme Alder som de Tørveprøver, der hænger fast ved Frugtlegemerne? Eller kan det tænkes, at disse er sunkne ned i ældre Lag, og at der fra disse har hæftet sig Tørvesubstans fast ved deres Overflade? Spørgsmaalet lader sig næppe fyldestgørende besvare paa Grundlag af det sparsomt fundne Materiale, men i Betragtning af Frugtlegemernes ringe Vægt og store Udstrækning er det usandsynligt, at der kan blive Tale om en Ned- 
synkning i ældre Lag af nogen større Betydning, saa der formodentlig kun i ganske enkelte Tilfælde vil være Grund til at regne med en saadan. I det store og hele vil vel Tørveresternes Aldersbestemmelse kunne direkte overføres paa Polyporus-Frugtlegemerne. Ved alle Aldersbestemmelserne maa man imidlertid regne med en vis Usikkerhed paa Grund af Tørveprøvernes Lidenhed, deres ofte ret tilfældige Forekomstmaade paa og i Svampen samt en Mulighed for Forurening gennem recent Pollenregn. Resultaterne af Pollenanalyserne bør derfor kun benyttes til en omtrentlig Aldersangivelse.

Nedenfor gives en tabellarisk. Oversigt over Pollenspektrene fra danske Mosefund af Tøndersvamp. I enkelte Tilfælde lykkedes det ikke trods gentagne "Skrab« at fremskaffe tilstrækkeligt Tørvemateriale til en sikker Pollenanalyse. Alderen af disse Fund lader sig derfor næp bestemme. Dette gælder Fundene Nr. 3, 7 og 9. Med Hensyn til den tabellariske Oversigt vil det være paa sin Plads at gøre opmærksom paa et Par Punkter. Pollentallene er angiven i \% af den samlede Skovtræ-Pollenmængde $\div$ Corylus, hvilket ogsaa gælder »Pollentallene« for Corylus selv (i Tabellens sidste Rubrik). Proportionstallet $\frac{\text { Egeblandingsskov }}{\text { Fyrreskov }}$ er beregnet paa de absolutte Antal Pollen, ikke paa Procenttallene. „Egeblandingsskov« omfatter her Quercus + Tilia + Ulmus.

TABEL I

Pollenspektre fra danske Mosefund af Tondersvampen (Polyporus fomentarius).

\begin{tabular}{|c|c|c|c|c|c|c|c|c|c|c|c|c|c|c|c|}
\hline 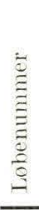 & Findesteder & 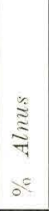 & $\begin{array}{l}\Xi \\
\Xi \\
\Xi \\
0\end{array}$ & $\mid \begin{array}{l}\stackrel{3}{\Xi} \\
\stackrel{\Xi}{\Xi} \\
0^{\circ}\end{array}$ & 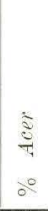 & 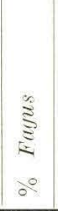 & 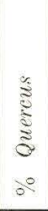 & 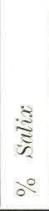 & $\begin{array}{l}\stackrel{2}{\approx} \\
0\end{array}$ & 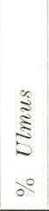 & 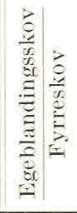 & 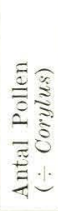 & 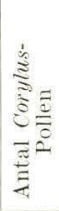 & 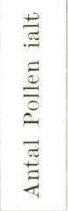 & 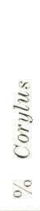 \\
\hline 1 & Stop so........ & 20 & 65 & 2 & - & - & 3 & - & 7 & 3 & 5,7 & 133 & 14 & 147 & 11 \\
\hline 2 & Hogild Mose... & 32 & 64 & 1 & - & 一 & 1 & - & 2 & -. & 2,5 & 171 & 33 & 204 & 19 \\
\hline 4 & Barlose ....... & 17 & 50 & 22 & & 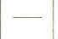 & - & - & - & 11 & 0,5 & 18 & 9 & 27 & 50 \\
\hline 5 & Brandeskov.... & 52 & 30 & 1 & 1 & 4 & 6 & 1 & 3 & 1 & 11,0 & 70 & 16 & 86 & 23 \\
\hline 6 & Aabymark..... & 17 & 50 & 5 & 一 & - & 2 & & 24 & 2 & 6,0 & 42 & 20 & 62 & 48 \\
\hline 10 & Udsholt........ & 29 & 38 & 16 & - & - & 2 & 1 & 9 & 5 & 1,0 & 126 & 55 & 181 & 30 \\
\hline 12 & Lillemose. . . . . & 13 & 60 & 13 & - & 3 & 2 & - & 7 & 2 & 1,1 & 55 & 24 & 79 & 44 \\
\hline 13 & Gallemose..... & 37 & 3 & 34 & 一 & & 3 & & 20 & 3 & 0,8 & 30 & 16 & 46 & 53 \\
\hline 15 & Bornholm...... & 18 & 47 & 27 & 一 & Spor & 一 & - & 8 & - & 0,27 & 40 & 18 & 58 & 45 \\
\hline 16 & ? Gallemose... & 2 & 47 & 47 & - & - & 4 & 一 & & - & 0,07 & 59 & 17 & 76 & 29 \\
\hline
\end{tabular}


11. 12

1. Stop Sø ved Viborg. Ved Analysen fandtes 35 Pollen pr. $\mathrm{cm}^{2}$ i ret tyndt Præparat. Foruden de i Tabel I anførte Pollen noteredes der Sporer af Lycopodium clavatum, af Sphagnum sp. samt af en Bregne (Dryopteris fitix mas?). Analysen af denne Prøve viser en ejendommelig Overensstemmelse med Prøven fra Høgild Mose Fundet (Nr. 2). Begge Spektrene viser hen til Egeblandingsskovens Periode, vel nok til dennes mellemste eller senere Del, idet Skovfyrren ikke længere spiller nogen Rolle, medens Bøgen endnu ikke har indfundet sig. Tiden kan nærmest sættes til atlantisk Tid, men maaske op mod eller eventuelt lige i Begyndelsen af subboreal Tid. Det kunde synes, som om Høgild Mose Fundet er ældre end Stop Sø Fundet, men det ringe Talmateriale for de vigtigste Skovtræers Vedkommende, Mangelen paa lokalt Sammenligningsmateriale samt endelig det Forhold, at særlig Høgild Mose Prøven giver Anledning til den Mistanke, at en Del mindre bestandige Pollenarter kan være decimerede, gør, at det ikke er muligt at indlade sig paa en mere detailleret Bestemmelse af de paagældende Frugtlegemers Alder.

2. Høgild Mose. Ved Analysen fandtes tillige Sphagnum-Sporer. Angaaende Tørveresternes Alder, som nærmest maa henregnes til den mellemste eller senere Del af Egeblandingsskovens Periode, henvises der til Diskussionen af Stop Sø Fundet (Nr. 1).

3. "Gaardsmose«, Grarup. Ved Tællingen observeredes kun 2 Pollen af Alnus, 8 af Betula, 2 af Titia samt 7 Corylus-Pollen. De to Linde-Pollen var stærkt destruerede, næsten usynlige; da der iøvrigt ikke iagttoges Pollen af de andre vigtige, »afgørende« Skovtræer, vil det sige, at selv om man ofrede et urimeligt stort Antal Timer paa Tællingsarbejdet, er dog Tørveresterne for fattige til, at man kan tillægge en saadan Pollentælling nogen Værdi for en Aldersbestemmelse.

4. Barløse. Der fandtes ved Analysen 4-5 Pollen pr. $\mathrm{cm}^{2}$. Skønt der kun taltes ialt 27 Pollen, hvoraf 9 Corylus-Pollen, synes Proportionen 0,5 dog at vise hen til Fyrreperiode, omend noget afgørende ikke kan siges.

5. Brændeskov. Foruden de i Tabellen opførte Pollen fandtes der ved Analysen Amphitrema flavum, Pollentetrader af Ericales og Sporer af Sphagnum sp. Proportionen $\frac{\text { Egeblandingsskov }}{\text { Fyrreskov }}$ : 11,0 viser afgjort hen til yngste Egeblandingsskovperiode.

6. Aabymark. Analysen opviste tillige Sporer og Bladfragmenter 
af Spagnum sp. Proportionen $\frac{\text { Egeblandingsskov }}{\text { Fyrreskov }}: 6,0$ angiver mellemste til yngre Afsnit af Egeblandingsskoven.

7. Vængemose. Ved Analysen fandtes kun 2 Pollen af Betula, et halvt Pollen af Pinus, et af Acer samt 3 Corylus-Pollen. Et virkeligt Spektrum lader sig derfor ikke opstille uden Anvendelse af urimelig megen Tid til Tællingen, og det derved eventuelt vundne Resultat vilde ydermere i saadant Tilfælde være af tvivlsom Værdi. De iagttagne Pollen viser dog, at Svampen næppe er saa gitmmel som den ældre Del af Fyrreperioden.

8. Maglemose ved Mullerup. Svampens Alder er givet gennem selve Fundomstændighederne, nemlig en Boplads fra Fildste Stenalder, »Mulleruptid« eller sen Fyrreperiode. En Slags Verifikation ved Pollenanalyse af Frugtlegemets Tørverester lader sig ikke udføre, da Svampen, ejendommelig nok, ikke længere synes at eksistere.

9. Skaverup. Afskrabningsmassen fra de to Frugtlegemer lod sig ikke »pollentælle«; i Prøven fra den ene Svamp fandtes 1 Corylus-Pollen.

10. Udsholt, Græsted. Der fandtes 31 Pollen pr. $\mathrm{cm}^{2}$, tillige Sphagnum-Sporer. Til Trods for at ikke færre end 180 Pollen taltes, og Proportionen $\frac{\text { Egeblandingsskov }}{\text { Fyrreskov }}$ er 1,0, kan der om Prøvens Alder næppe siges meget andet end: Egeblandingsskovens Periode, sandsynligvis et ret tidligt Afsnit af denne.

11. Maglemose, Grib Skov. Krud Jessen (1920, S. 105) angiver følgende Spektrum for det Lag (D, Alle-Birkeskovtørv), hvori Frugtlegemet fandtes: Alnus 78, Betula 5, Pinus 3, Quercus 5, Tilia 9 samt Corylus $6 \%$. Forholdet $\frac{\text { Egeblandingsskov }}{\text { Fyrreskov }}$ er 4,7 og angiver Egeblandingsskovperiode (mellemste?).

12. Lillemose. Ved Analysen iagttoges tillige Amphitrema flavum og Bladfragmenter af Sphagnum sp. Bøgepollenets Tilstedeværelse peger paa et yngre Afsnit af Egeblandingsskovens Periode, men saafremt man kunde antage, at de talte to Bøgepollen var tilkomne ved Forurening, vilde Spektret i sin Helhed og Proportionen 1,1 egentlig passe langt bedre paa ældste Egeblandingsskovperiode, lidt yngre end Mulleruptiden. Stennstrup angav jo blot: Egetiden og troede aabenbart - at dømme fra hans Anvendelse af Navnet "Egesvampen« — at den fundne Svamp har vokset paa Eg. 
11. 14

13. Gallemose. Pollenspektret viser, at alle vigtigere skovdannende Træer var indvandrede paa det Tidspunkt, da Svampen blev indlejret i Tørvelagene; Proportionen $\frac{\text { Egeblandingsskov }}{\text { Fyrreskov }}$ 0,8 angiver, at Tørveprøvens Alder maa henføres til Slutningen af Fyrreperioden (eller eventuelt til det allertidligste Afsnit af Egeblandingsskovens Tid), altsaa Mulleruptiden (eller eventuelt lidt yngre). Ejendommeligt er det, at Betula-Pollen næsten ganske mangler.

14. Nysted Nor. Frugtlegemets Alder er — ligesom for Mullerup-Fundets Vedkommende - givet gennem selve Fundomstændighederne, nemlig Aldre Stenalder (ældre og mellemste Egeblandingsskovperiode).

15. Bornholm. Foruden de i Tabellen opførte Pollen fandtes der ved Analysen et Fagus-Pollen, som dog næppe hører sammen med de øvrige Pollenkorn, men maa betragtes som en Forurening; yderligere iagttoges Sporer og Bladfragmenter af Sphagnum samt Rhizopoden Amphitrema flavum. Proportionen $\frac{\text { Egeblandingsskov }}{\text { Fyrreskov }}$ : 0,27 viser - naar man ser bort fra det ene Fagus-Pollen - hen til Fyrreperiodens mellemste eller sidste Del. Efter Angivelse af Professor KNud Jessen synes det imidlertid at være karakteristisk for Bornholm, at Fyrren dér holder sig med høje Procenttal helt hen i den postlitorinale Tid. Da Tilia, der her er repræsenteret af $8 \%$ Pollen, snarest indvandrede senere end Quercus og Ulmus, og da Manglen paa Quercus og Ulmus i Analysen kan være betinget af, at disses Pollen destrueres lettere end Titia-Pollenet, er der trods det lave Proportionstal alligevel Grund til at henføre Fundet til yngste Fyrreperiode (eller endog Begyndelsen af Egeblandingsskovens Periode?).

16. ? Gallemose. Spektrets meget høje Procent for Pinus-Pollen samt Proportionen 0,07 viser utvivlsomt hen til Fyrreperioden. Da Talmaterialet er saa ringe ved denne Tælling, repræsenterer de $4 \%$ Quercus-Pollen i Virkeligheden kun eet sikkert bestemt og eet tvivlsomt Pollen, hvorfor den Mulighed foreligger, at Quercus slet ikke har leveret Pollen til det Tørvelag, hvoraf Rester hænger ved Frugtlegemerne. Spektret fra nærværende Fund sammenlignet med det fra Nr. 13 (Gallemose), af hvilke det førstnævnte afgjort viser størst Flde, taler i hvert Fald ikke imod den Antagelse, at ogsaa dette Fund, om hvilket der ganske savnes Oplysninger, stammer fra Gallemose.

I Tabel II, Side 15, er givet en tabellarisk Oversigt over Alderen af Fundene, saaledes som denne er blevet bestemt dels paa Grund- 
lag af pollenstatistiske Undersøgelser, dels ad arkæologisk Vej. Det vil være rigtigt atter her at betone, at Aldersangivelserne kun er omtrentlige og sikkert behæftede med ret store Fejl, Fejl, som det imidlertid foreløbigt vil være umuligt at rette.

\section{TABEL II}

Alderen af Fund af Tondersvampen (Polyporus fomentarius) fra Postglacialtiden.

\begin{tabular}{|c|c|c|c|}
\hline \multicolumn{2}{|c|}{ Skovudviklingen } & Arkieologiske Perioder & \\
\hline \multicolumn{2}{|c|}{ Bogeperiode } & Jærnalder & Ingen Fund \\
\hline \multirow[b]{2}{*}{$\begin{array}{l}\text { Egeblan- } \\
\text { dingsskovs- } \\
\text { Periode }\end{array}$} & yngste & Bronzealder & Brændeskov (5) \\
\hline & $\begin{array}{l}\text { mellemste } \\
\text { og } \\
\text { xldre }\end{array}$ & $\begin{array}{c}\text { Yngre og Eldre } \\
\text { Stenalder }\end{array}$ & $\begin{array}{l}\text { Aabymark (6) } \\
\text { Stop Sø (1) } \\
\text { Maglemose, Grib Skov (11) } \\
\text { Hogild Mose (2) } \\
\text { Lillemose (12) } \\
\text { Udsholt (10) } \\
\text { Nysted Nor (14) }\end{array}$ \\
\hline \multirow{2}{*}{$\begin{array}{l}\text { Fyrre- } \\
\text { periode }\end{array}$} & yngre & Mulleruptid & $\begin{array}{l}\text { Bornholm (15) } \\
\text { Maglemose, Mullerup ( } 8) \\
\text { Gallemose (13) } \\
\text { Barlose (4) }\end{array}$ \\
\hline & ældre & & ? Gallemose (16) \\
\hline
\end{tabular}

Ubestemt Alder: Grarup (3), Væengemose (7), Skaverup (9).

Som Hovedresultat af disse Forsøg paa Aldersbestemmelser kan det altsaa fastslaas, at et enkelt af Polyporus-Fundene synes at hidrøre fra ældre Fyrreperiode og et mindre Antal fra yngre Fyrreperiode (Mulleruptiden, »Eldste Stenalder «), medens Størsteparten stammer fra Egeblandingsskovens Periode (AEldre og Yngre Stenalder samt en Del af Bronzealderen). Tre Fund har ikke kunnet tidsfæstes. - Det synes herefter sikkert, at Polyporis fomentarius har været her i Landet et Par Aartusinder eller mere, før Bøgen indvandrede, medens det er uoplyst, om den kom hertil samtidig med eller snart efter de storbladede Birkes Ankomst. Det Fund, der bestemt efter Pollenanalysen — viser størst Alde, nemlig Nr. 16. (? Gallemose), maa regnes for at hidrøre fra et Tidspunkt af Postglacialtiden, da Pollenregnen indeholdt 47\% Betula-Pollen, altsaa 
fra et væsentlig yngre Tidspunkt end de storbladede Birkes Indvandring. Naar der ikke foreligger nogen tidsbestemt Polyporus fomentarius fra Bøgeperioden, maa det vel bero paa en Tilfældighed, altsaa utilstrækkeligt Fundmateriale.

I Tilslutning hertil kan det nævnes, at der hverken fra danske interglaciale eller tertiære Aflejringer kendes Fund af PolyporusArter.

Efter nu at have gjort Rede for Alderen af de fundne Poresvampe vil det være naturligt at undersøge, hvilken, eventuelt hvilke Arter de paagældende Fund tilhører. Som ganske kort berørt i Indledningen er der adskillige af de fleraarige, træ- eller korkagtige Polyporus-Arter, der egner sig fortrinlig til Opbevaring gennem lange Tidsrum, og det vilde derfor være rimeligt at vente, at Gravninger i Moserne havde bragt Levninger af disse Arter for Dagen. Gennemgaar man nu de tidligere Bestemmelser, hvor saadanne foreligger, Bestemmelser, som for en væsentlig Del hidrører fra EMIL Rostrup, vil man finde, at Fundene fejlagtigt har været henført til enten Polyporus igniarius (L.) Fr., Ild-Poresvampen eller den uægte Tønder-(Fyr)-svamp ${ }^{1}$ ), eller til P. nigricans $\left.{ }^{2}\right)$ Fr., en usikker Art, som dog vel nærmest bør opfattes som en sortagtig Varietet af førstnævnte Art. En nøje Undersøgelse har dog godtgjort, at det i alle Tilfælde drejer sig om Polyporus fomentarius (L.) Fr., den ægte Tønder- eller Fyrsvamp. Aarsagen til Fejlbestemmelserne maa vel søges dels i Frugtlegemernes mørke, brun- til næsten kulsorte Farve, dels i den hyppigt paa Kryds og tværs sprukne, ofte stærkt forvitrede Overflade, Karakterer, som begge passer paa $P$. igniarius og $P$. nigricans, naar denne, saaledes som det nu almindelig sker, opfattes som en Varietet af $P$. igniarius. Imidlertid skyldes den mørke Farve og den sprukne Overflade Frugtlegemernes lange Henliggen i Moserne. Som afgørende Kriterier for, at de subfossile Svampe maa henføres til Tøndersvampen, kan blandt andet nævnes Tilstedeværelsen af det tønderagtige Trama og den hornagtige Skorpe.

Efter at have naaet til Klarhed over at det drejer sig om Polyporus fomentarius i alle de nærmere undersøgte Tilfælde, vil det være af Interesse at faa oplyst, hvilke Værtplanter den har vokset paa. I Nutiden er de vigtigste Værter for denne Svamp i Danmark først og fremmest Fagus og dernæst Betula; nogle enkelte Gange

1) Fejltagelsen gaar desværre igen hos JENS Lind (1913); Lind skriver her S. 384: "Rostrup has found it [se. Polyporus igniarius] in several places in peat-bogs, and Sophus Møller [skal være: MüLLER] has found it among broken tools from the fireplaces of our ancestors".

2) Se bl. a. under Omtalen af Fund Nr. 15 (Bornholm). 
er den fundet paa andre Træer, bl. Acer, Populus, Quercus, Ulmus (Buchwald 1930, S. 61-65). Ved en Opregning af Fortidens Værtplanter kan formodentlig de sidstnævnte derfor lades ude af Betragtning, saaledes at Talen kun bliver om Fagus og Betula. I de forholdsvis faa Tilfælde (Nr. 4, $11 \mathrm{og}$ 15), hvor der endnu - i Form af Bark eller Ved - sidder Rester af Værtplanten tilbage, er det en forholdsvis let Sag at afgøre Spørgsmaalet; det har i alle de nævnte tre Tilfælde vist sig at være Birk (Betula pubescens). Det er tidligere paavist (BuCHWALd 1930, S. 54-57), at Svampens Bøgeform ( $f$. fagi) og Birkeform ( $f$. betulae) i mange Tilfælde morfologisk lader sig adskille, idet førstnævnte Form i Reglen er langt større, i Tværsnit halvkredsformet samt relativ lav, medens Birkeformen er lille, i Tværsnit ofte nyreformet samt relativ høj. En Gennemgang af Længdemaalene for de subfossile Frugtlegemers Vedkommende viser, at Størrelsen i alle Tilfælde, med Undtagelse af to (Nr. 16 a og $16 \mathrm{~b}$ ), ligger under, ja hyppigt langt under, Middellængden for Bøgeformen; mange af Frugtlegemerne er høje og typisk nyreformede i Tværsnit; da Bøgepollen endvidere kun er fundet ved to af Fundene og tilmed i sparsom Mængde, er der overvejende Sandsynlighed for, at alle eller i hvert Fald den ganske overvejende Part af Frugtlegemerne hidrører fra Betula. Dette Forhold kan heller ikke undre; det hænger dels sammen med, at Bøgen i mange af Tilfældene endnu ikke var indvandret, dels beror det — i de Tilfælde, hvor Bøgen havde indfundet sig — paa de to Værtplanters forskellige Standpladser. Vore forhistoriske Birkeskove og -krat dannedes fortrinsvis af den moseyndende Dunbirk (Betula pubescens); de væltende Birkestammer med deres eventuelt paasiddende Poresvampe faldt direkte om i Mosen og indlejredes i Tørvelagene. Af Bøgen derimod, som jo ikke er noget Mosetræ, finder man kun undtagelsesvis Levninger af Stammer og større Grene og dermed ogsaa af Poresvampe, almindeligvis kun Blade, Pollen og Frugter, som Vinden kan have ført ud i Mosen.

Af subfossile Poresvampe kendes altsaa hidtil fra Danmark kun Tøndersvampen (Polyporus fomentarius). I Forbindelse med Konstateringen af dette Forhold vil det være naturligt at give en kort Oversigt over, hvad man kender til subfossile Polyporus-Fund i de øvige nordiske Lande.

For Finlands Vedkommende synes Polyporus-Arter ikke at være sjældne i Moserne, efter hvad Gunnar Andersson (1898, S. 140) skriver: "Polyporus förekommer ej sällan i mossarne, särskildt i 


\section{18}

grandy. Svampen har, om man frånser den mörkare färgen, alldeles samma utseende som i lefvande tillstånd och artbestämning är därför lätt värkställd. Ett mycket stort exemplar, som jag anträffade vid Pähkinämäki i Suontakadalen Kar. [elen] har af stud. A. THeSLEFF bestämts till $P$. igniarius (L.) Fr.«

Fra Norge omtaler J. Ноцмвое (1904, S. 112) et Fund af en Poresvamp fra Startørv i Egezonen i en Mose paa Jæderen; der fandtes kun Brudstykker; Svampen bestemtes til P. igniarius. — I et Brev (6. 4. 1929) fra Statsmykolog J. Jörstad, Oslo, meddeles følgende: "Der er funnet ett subfossilt eks. av $P$. fomentarius, som er mærket: "Jæderens rev, 1903«. Finneren er ukjent, og eksemplaret blev for ikke længe siden tilfeldigvis funnet i herværende museums kjeller. . . . . Jærens rev ligger ikke langt fra det sted, hvor HoLmвоE i sin tid fandt den formentlige $P$. igniarius. Ellers kjenner jeg ingen subfossile funn af disse sopper.«

Fra Sverige foreligger der en kort Meddelelse af $H$. von Post (1865) om et Fund af Polyporus igniarius i en Mose i Östergötland.

Sammenfatter vi disse faa Oplysninger, der, saavidt Forff. bekendt, er de eneste, som findes for Skandinavien og Finlands Vedkommende, ses det, at de fleste af Fundene tilhører Polyporus igniarius, kun et enkelt — fra Norge - P. fomentarius. Forff. har ikke haft Lejlighed til at verificere Bestemmelserne; Forklaringen paa, at Mosefundene ganske overvejende tilhører Polyporus igniarius, og ikke som i Danmark Polyporus fomentarius, kan maaske søges deri, at den førstnævnte Poresvamp er den almindeligste af de to Arter i Skandinavien og Finland. 


\section{Summary.}

On postglacial finds of the tinder fungus (Polyporus fomentarius

$$
\text { (L.) Fr.) in Denmark. }
$$

Finds of postglacial fruit bodies of the tinder fungus (Polyporus fomentarius (L.) Fr.) are known from 16 different localities in Denmark. The localized finds are described in detail on p. 5-10, and the geographical distribution is given on the map on p. 6. Two of the finds (No. 8 and 14) were made in the deposits of the Stone Age; all the other finds originate from postglacial peat bogs. Three of the finds from bogs are well described (No. 11, 12 and 13), their age being given through the very circumstances under which they were found. In all other cases the age of the specimens has been determined by pollen-analysis of the masses of peat found on the surface and in the cavities of the fruit bodies; for in such cases it may be supposed that the age of the fungi largely corresponds to the age of the layers of peat in which they are found.

In table I on p. 11 is a list of the pollen-spectra of ten different fruit bodies found in bogs, and on table II on p. 15 all the finds are classified according to their age. From table II it will be seen that only one find (No. 16) dates back to the early pine period and four finds (No. 4, 8, 13 and 15$)$ to the later pine period. From the mixed-oak-forest period we know of 8 localities, the youngest find dating back to the Bronce Age (No. 5). Curiously enough no fruit bodies have been found from the beech period; the age of three finds (No.3,7 and 9) has not been determined.

Several of the specimens previously have been referred to Polyporus igniarius (L.) Fr. and P. nigricans Fr. by E. Rostrup and others, but this is not correct; all specimens belong to the species of Polyporus fomentarius (L.) Fr. In all cases where it has been possible to identify the remains of the substratum of the fungus, the host has turned out to be the birch (Betula pubescens). No other species of polypores have been found in Danish peat bogs. 


\section{Litteraturliste.}

\section{Forkortelser.}

D. G. U.: Danmarks Geologiske Undersøgelses Skrifter. København.

D. G. F.: Meddelelser fra Dansk Geologisk Forening. København.

Andersson, Gunnar. (1898). Studier öfver Finlands torfmossor och fossila kvartärflora. Bull. de la Comission géologique de Finlande, No 8. Helsingfors.

Buchwald, N. Fabritius. (1930). Tønder- eller Fyrsvampen (Polyporus fomentarius (L.) Fr.). Dens Naturhistorie, Historie og Anvendelse. Meddelelser fra Foreningen til Svampekundskabens Fremme IV. S. $49-92$. København.

Degerbøl, Magnus. (1933). Danmarks Pattedyr i Fortiden i Sammenligning med recente Former. I. Videnskabelige Meddelelser fra Dansk naturhistorisk Forening. Bd. 96. Festskrift II. København.

Holmboe, Jens. (1903). Planterester i Norske torvmyrer. Videnskabsselsk. Skrifter. I. Math.-naturv. Klasse, 1903, No. 2. Kristiania.

Jessen, Knud. (1920). Moseundersøgelser i det nordøstlige Sjælland. D. G. U. II. Række. Nr. 34.

- (1927). Et Kulturlag fra den ældre Stenalder ved Horsø. De geologiske Forhold. D. G. F. Bd. 7. (1927). Side 129.

- (1929). Bjørnen (Ursus arctus L.) i Danmark. D. G. F. Bd. 7 (1929) Side 273 og D. G. U. IV. Række. Bd. 2. Nr. 6.

Lind, Jens. (1913). Danish Fungi as represented in the herbarium of E. Rostrup. Copenhagen.

von Post, Hampus (1865). Fynd af en fossil svamp. Botaniska Notiser för år 1865. S. 82. Stockholm.

Rostrup, Emil. (1858). Beskrivelse af "Gallemosen" paa Lolland. Videnskabelige Meddelelser fra den naturhistoriske Forening i København.

- (1883). Fortsatte Undersøgelser over Snyltesvampes Angreb paa Skovtræerne. Tidsskrift for Skovbrug. Bd. VI. S. 243. København.

Sarauw, Georg F. L. (1903). En Stenalders Boplads i Maglemose ved Mullerup, sammenholdt med beslægtede Fund. Aarbøger for nordisk Oldkyndighed og Historie. II. Række. Bd. 18. 3. Hæfte. Kjøbenhavn.

Steenstrup, Iapetus. (1842). Geognostisk-geologisk Undersøgelse af Skovmoserne Vidnesdam- og Lillemose i det nordlige Sjelland. Vid. Selsk. naturv. og math. Afd. IX. Del. Kjøbenhavn 1842. (Særtryk 1841),

Ødum, Hilmar. (1920). Et Elsdyrfund fra Taaderup paa Falster. D. G. U. IV. Række. Bd. 1. Nr. 11. 
FR, BAGGES KGL, HOFBOGTRYKKERI KØBENHAVN 